1. Arquiteto e urbanista pela Escola de Arquitetura da Universidade Federal de Minas Gerais, planejador territorial e urbanista pelo Istituto Universitário di Architettura di Venezia - IUAV- Itália, mestre em Arquitetura pela EA-UFMG e doutorando em Tratamento da Informação Espacial pelo Programa de Pósgraduação em Geografia, Tratamento da Informação Espacial da PUC Minas, professor das disciplinas de Planejamento Habitacional, Política Habitacional e Projeto de Urbanismo do Curso de Graduação em Arquitetura e Urbanismo da PUC Minas.

2. Arquiteta e urbanista formada pela PUC Minas.

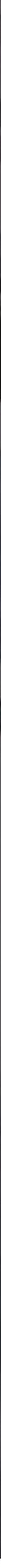




\title{
MOBILIZACÃO \\ SOCIOAMBIENTAL PARA \\ NOVAS FORMAS DE \\ AUTOGESTÃO: O CASO DA \\ VILA NOVO OURO PRETO
}

ENVIRONMENTAL AND SOCIAL MOBILIZATION FOR NEW FORMS OF SELF-

MANAGEMENT: THE CASE STUDY OF VILA NOVO OURO PRETO

\author{
Alfio Conti \\ Adriana Ribeiro Gouveia²
}

\begin{abstract}
Resumo
O artigo analisa o processo de mobilização, de melhoria urbana e ambiental que culminou na elaboração do Plano Global Específico da Vila Novo Ouro Preto; são analisadas também as fases de implementação desse instrumento urbanístico, destacando-se, além de suas características, seus limites estruturais, bem como sua dependência da mobilização e articulação da comunidade local.
\end{abstract}

Palavras-chave: Planejamento local; Habitação; Movimentos sociais.

\begin{abstract}
This article analyzes the process of mobilization, urban and environmental improvement which led to the elaboration of the Specific Global Plan of Vila Novo Ouro Preto. The phases of implementation of that urban instrument are also analyzed, with emphasis on its characteristics and structural limits, besides its dependence on the local community's mobilization and articulation.
\end{abstract}

Key words: Local planning; Housing; Social movements. 


\section{Localização e breve histórico}

Localizada na Regional da Pampulha, nos limites do Bairro Ouro Preto, em Belo Horizonte, a Vila Novo Ouro Preto está situada num pequeno vale orientado no sentido norte-sul, inserido na bacia da Lagoa da Pampulha. O curso de água principal é o Córrego da Cidadania, que deságua na Lagoa da Pampulha após um percurso de pouco mais de seis quilômetros. A Vila Novo Ouro Preto localiza-se na área da nascente do córrego e, a partir dela, ao longo de suas margens, por um total de 0,4 quilômetros.

O processo de implantação e crescimento da Vila, assim como acontece em muitas situações análogas, caracteriza-se por uma ocupação inicial dos terrenos de meia encosta, com declividades menores, relativamente protegidos e com baixo risco de inundação e, sucessivamente, pela ocupação das áreas remanescentes e de parte do leito do córrego, aumentando sensivelmente, para essas famílias, o risco de inundações e alagamento.

As áreas ocupadas em geral apresentam grandes declividades e o afloramento de rochas localizado próximo ao leito do córrego, associado à declividade, gera um aumento do risco de deslizamento devido à instabilidade do solo. Em geral, a maioria das residências está sujeita a algum tipo de risco geotécnico.

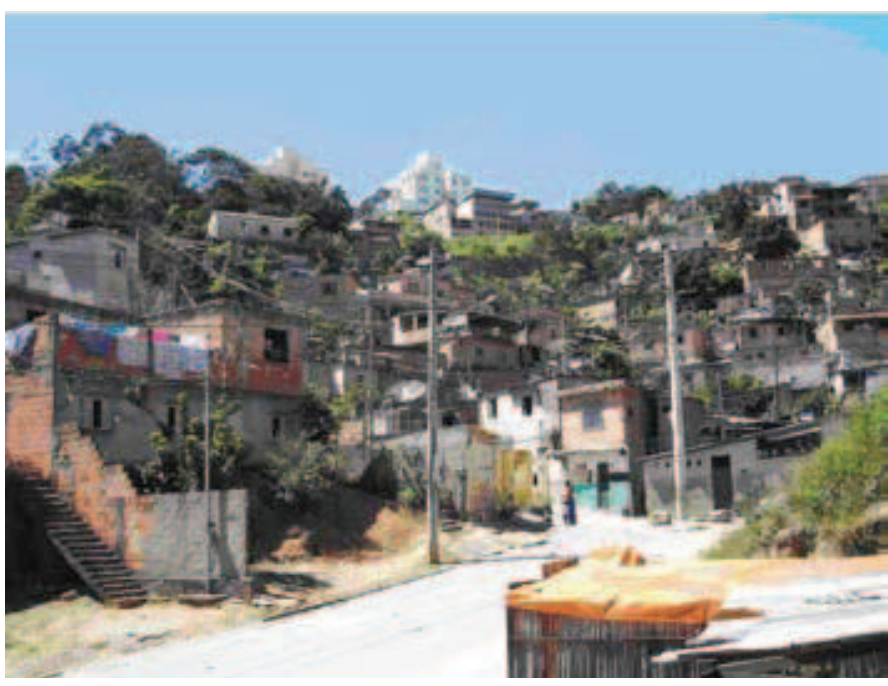

As ocupações da área começaram por volta de 1966 na porção norte, nas áreas de menores declividades, nas margens do córrego. Hoje, essa região corresponde à entrada da Vila. As ocupações na porção sul, caracterizada por áreas de maiores altitudes e declividades, começaram por volta de 1970, registrando um crescimento populacional significativo a partir de 1975. Em 1989 a área da microbacia do Córrego da Cidadania já estava totalmente ocupada.

O boom do crescimento demográfico foi na década de 1990, quando a população dobrou, causando, junto com o grande adensamento, o início do processo de verticalização das edificações. Como consequência desse crescimento instalou-se, de fato, um processo de degradação ambiental com duas vertentes:
Figura $1 \bullet$ Vista da entrada da Vila Novo Ouro Preto pela Rua Luiz Lopes antes das obras previstas pela implementação do parque linear (foto da autora).

Cadernos de Arquitetura e Urbanismo, v.16, n.18+19, 2009 
- a vertente da degradação da qualidade de vida associada ao espaço edificado, com o aumento dos problemas relacionados ao conforto das edificações, especialmente no que diz respeito à iluminação natural e à ventilação, com a elevação, em geral, do grau de insalubridade;

- a vertente da degradação da qualidade de vida associada ao espaço não edificado, com o aumento dos problemas ambientais por causa, principalmente, do impacto produzido pelo lixo doméstico que, despejado de qualquer maneira e sobretudo no leito do córrego, aumentou a poluição das águas desde as nascentes, tornando o córrego um verdadeiro esgoto a céu aberto.

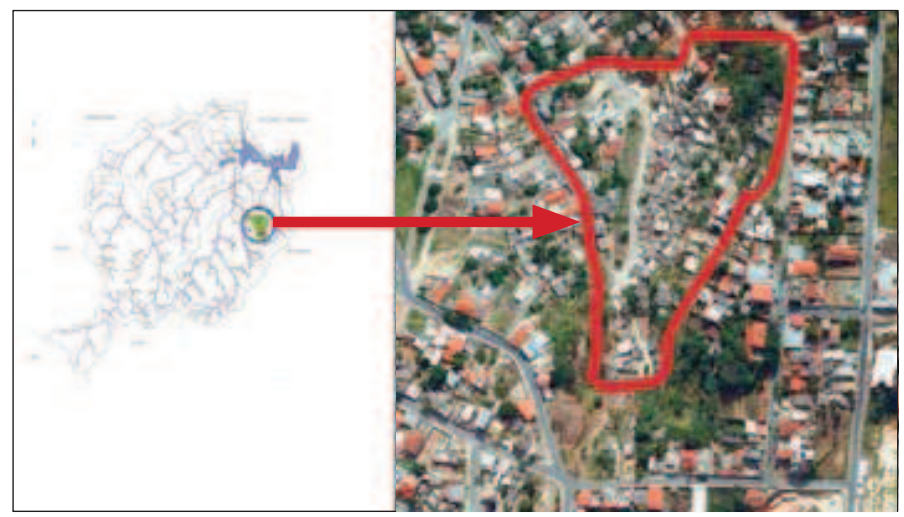

\section{Aspectos físico-ambientais e socioeconômicos}

\section{Aspectos físico-ambientais}

Inserida em um talvegue encaixado e profundo, definindo um anfiteatro no sentido Norte-Sul, a Vila Novo Ouro Preto apresenta encostas com declividade, em sua maior parte, superior a $47 \%$. O risco de deslizamento e solapamento, além do risco de inundação das casas que se localizam às margens do córrego ou dentro da sua faixa de domínio, aliado à declividade e à fragilidade estrutural das construções, qualificam essa área como de alto risco geológico. Levantamentos físicos ambientais para elaboração do Plano Global Específico - PGE1 indicam que metade da área da Vila possui risco geológico, sendo que 10\% encontram-se em situação de risco iminente ou alto. Na porção norte do talvegue encontra-se a maior parte das edificações, devido às declividades mais baixas. Trata-se da porção da Vila mais adensada e com os maiores problemas de conforto ambiental, como deficiência na iluminação natural e ventilação, pois o vento dominante em Belo Horizonte é no sentido leste-oeste e o talvegue torna-se uma barreira física. Esses fatores aumentam a insalubridade do lugar e os problemas de saúde. As moradias situadas nas cotas mais altas do terreno, afastadas da aglomeração, porém assentadas sobre as linhas de drenagem, sofrem com problemas de umidade.

Como agravante, todo o esgoto produzido pelos moradores e do entorno imediato é despejado no córrego sem qualquer tratamento. Em contrapartida, a presença das nascentes ou surgên-
Figura 2 • Localização da Vila Novo Ouro Preto dentro da Bacia da Pampulha e vista aérea.
1. O Plano Global Específico é utilizado pela Companhia Urbanizadora de Belo Horizonte - Urbel - como instrumento para a requalificação de vilas e favelas. Discutido mais adiante neste trabalho.

Cadernos de Arquitetura e Urbanismo, v.16, n.18+19, 2009 


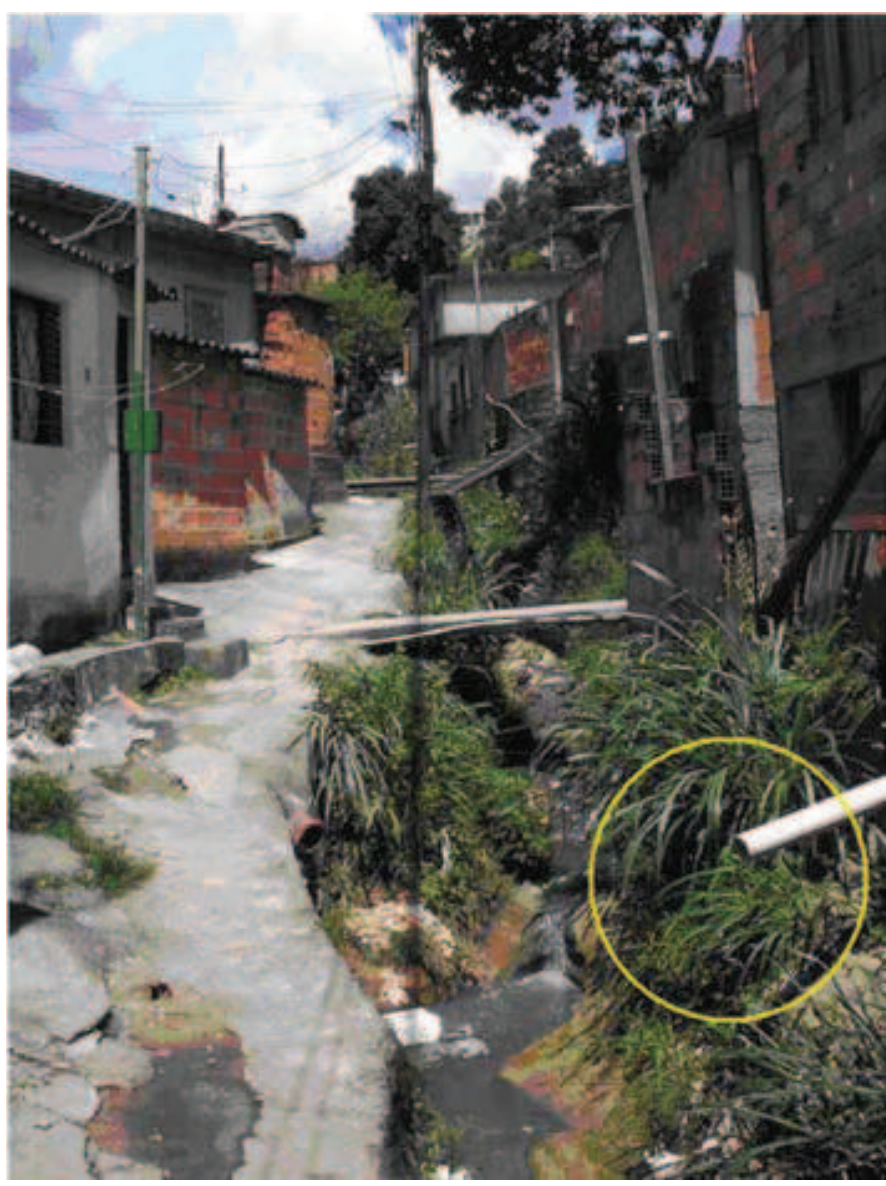

cias de água possibilita uma alternativa de abastecimento hídrico aos moradores. O abastecimento de água chega a mais da metade dos domicílios que estão conectados à rede oficial por meio de hidrômetro e a totalidade das edificações é servida por energia elétrica, sendo $85 \%$ por padrão e 15\% através de "bico".2 Segundo dados do censo do IBGE de 1991, 94\% dos domicílios despejavam seu lixo nas áreas livres ou dentro do córrego. De acordo com dados do PGE, 90\% dos domicílios depositam seu lixo em três cestos comunitários situados na rua Luiz Lopes; já no beco Otaviano Neves a coleta é feita de porta em porta.

\section{Sistema viário}

O sistema viário é articulado por um conjunto de becos que servem exclusivamente à circulação de pedestres. Os becos principais, Beco 1 e Beco Luiz Lopes (ambos continuação da rua Luiz Lopes), cortam a Vila no sentido longitudinal, enquanto os becos secundários fazem a ligação destes com a parte mais alta, onde existem situações de desarticulação e de descontinuidade do sistema viário. Dos becos principais, o mais importante é o Beco 1 , que se desenvolve no fundo do vale, paralelamente ao córrego, verdadeira espinha dorsal articuladora de todo o sistema viário. Um mapa-síntese da Vila Novo Ouro Preto com indicação do sistema viário (ruas e becos) e demais informações sobre a área e adjacências é apresentado anexo a este trabalho.
Figura $\mathbf{3} \cdot$ Beco Um - O esgoto era lançado diretamente no córrego (foto da autora)

2. O "bico" é uma prática utilizada para economizar no custo do serviço prestado pela concessionária e consiste em dividir o custo do serviço por vários usuários, pagando uma taxa só de serviço. Outra prática é o chamado "gato", que consiste em ligações clandestinas. 
O córrego da Cidadania encontra-se canalizado sob parte da rua Luiz Lopes, principal entrada para a Vila localizada no fundo do vale, sendo também a única rua transitável por caminhões. Essa rua faz a transição entre o bairro e a favela.

Outros importantes acessos são dados pela rua Otaviano Neves, que se estreita ao alcançar os limites da Vila, impossibilitando a entrada de veículos, e pela rua Etel Nogueira de Sá, localizada na extremidade sul e situada no alto do talvegue, sendo o acesso dos moradores realizado através do chamado "escadão" e o último acesso dado por uma escadaria construída recentemente pela Companhia Urbanizadora de Belo Horizonte - Urbel - na rua Anita Barbosa.

\section{Aspectos socioeconômicos}

Como na maior parte das favelas brasileiras, também na Vila Novo Ouro Preto concentram-se baixo índice de escolaridade, alto nível de desemprego e baixa renda per capita, caracterizando um quadro de alto risco social e expondo seus moradores, principalmente os mais jovens, aos atrativos da criminalidade. Como contrapartida verifica-se, porém, nessa comunidade um alto nível de solidariedade e ânimo para a atuação coletiva.

Segundo informações contidas no PGE, a Vila Novo Ouro Preto conta hoje com aproximadamente 1.500 habitantes distribuídos em mais de 300 domicílios. A densidade média é altíssima (341 hab./ha), se comparada com a densidade média da regional da Pampulha (25,8 hab./ha) e com a densidade do município de Belo Horizonte (59,7 hab./ha). No que diz respeito às faixas etárias, $66 \%$ da população está abaixo de 16 anos de idade e menos de $2 \%$ acima de 65 anos. Hoje, mais de $20 \%$ da população economicamente ativa está desempregada, sendo que a parte empregada, 25\%, ganha em média um salário mínimo mensal.

No que diz respeito à dotação de equipamento de saúde pública, a Vila encontra-se desprovida. Em caso de necessidade, a comunidade deve utilizar os centros de saúde localizados nos bairros limítrofes. As doenças respiratórias são a maior causa dos atendimentos, provocadas principalmente pela umidade excessiva das residências.

A escolaridade média está entre a $5^{\mathrm{a}}$ e $6^{\mathrm{a}}$ séries do ensino fundamental e a taxa de alfabetização é de $82,3 \%$ da população acima de 14 anos. Apenas 5,7\% frequentam segundo grau e 0,5\% dos moradores têm curso superior. Para fazer frente a essa situação, há na Vila um programa de alfabetização solidária que atende os moradores, apesar de o índice de evasão ser alto.

No que diz respeito a equipamentos de segurança como delegacia ou posto de polícia, a Vila não dispõe de nenhum deles.

\section{A mobilização da comunidade do começo até o final da década de 1990}

O início do processo de mobilização popular na Vila remonta ao final dos anos 1970, quando, juntamente com os moradores do bairro Ouro Preto, foi fundada a primeira associação para representar os interesses da comunidade, que recebeu o nome de 
Associação dos Amigos do Bairro Ouro Preto e Adjacências. Embora o enfoque principal dessa associação fosse representar os interesses da comunidade junto à sociedade e ao poder público, o que se registrou foi apenas o uso instrumental do nome da Vila Novo Ouro Preto como forma de atrair atenção e recursos do poder público, mas pouco ou quase nada foi feito para a melhoria da infraestrutura básica da Vila e a qualidade de vida de seus habitantes.

Em 1992, com uma ação isolada da população, teve início a canalização do córrego sob parte da rua Luiz Lopes, realizada em regime de mutirão. Esse evento marca o início da mobilização da população da Vila.

A criação de uma associação que representasse de fato os interesses dos moradores da Vila foi resultado de um longo processo que se fortaleceu em 1996 e culminou em 1998 com a criação da Associação dos Moradores da Vila Novo Ouro Preto - Amacidadania, tendo como principal objetivo a melhoria da habitabilidade na Vila e, como enfoque, a preocupação com as questões ambientais e a gestão das águas.

O processo foi sustentado pela parceria criada com o Instituto Cidade - $\mathrm{IC}^{3}$ que à época buscava representantes ou líderes comunitários que apresentassem interesse e preocupações ambientais em comunidades carentes pertencentes à Bacia da Pampulha. A Regional Pampulha - RP, administração descentralizada da Prefeitura de Belo Horizonte - PBH, indicou ao IC, como possíveis candidatos, dois representantes: Édina Barbosa, da Vila Novo Ouro Preto, e Toninho, do bairro Jaraguá.

A proposta apresentada pelo IC era de capacitar as comunidades locais, através de um projeto de ação baseado na autogestão, para que se pudesse chegar a resolver os problemas locais. A proposta foi prontamente aceita pela representante da Vila Novo Ouro Preto e descartada pelo representante do bairro Jaraguá.

Não obstante a comunidade possuísse um histórico de participação nas sessões do Orçamento Participativo - OP, ${ }^{4}$ após o contato com o IC e a capacitação por meio da autogestão, a postura diante das propostas oriundas do poder público mudou. O processo de sensibilização da comunidade com relação aos problemas ambientais, trabalhado juntamente com a capacitação autogestionária, culminou na mudança de atitude dos moradores, que passaram de agentes espectadores a agentes opinantes e atuantes, assumindo uma postura crítica diante das propostas de intervenção apresentadas pelo poder público, chegando a recusar aquelas cujas soluções eram contra os princípios ambientais introjetados pela comunidade.

Ao longo do primeiro ano de trabalho junto ao IC houve um seminário sobre lixo, organizado pela Universidade Federal de Minas Gerais - UFMG e, pela primeira vez, a sociedade civil teve contato com os problemas socioambientais existentes na Vila Novo Ouro Preto. Alguns meses após esse evento houve, em Belo Horizonte, o Seminário Internacional de Águas e Meio Ambiente, patrocinado pelo governo federal através do Ministério do Meio Ambiente, e foi incluída, no roteiro do seminário, a pedido da líder comunitária, uma visita à Vila Novo Ouro Preto. Logo em seguida, realizou-se uma reunião entre os moradores da Vila e o
3. Instituto Cidade, organização não governamental que atua no desenvolvimento de projetos ambientais para a melhoria da qualidade de vida urbana e abriga, desde 1997, o Centro de Referência do Movimento de Cidadania pelas Águas de Belo Horizonte.

\begin{abstract}
4. O Orçamento Participativo - OP é uma prática adotada pelas administrações municipais progressistas para democratizar a gestão urbana. Consiste em uma cota de recursos colocados à disposição para a implementação de obras de melhoria urbana escolhidas pela população através de um processo de seleção.
\end{abstract}


IC, onde surgiram propostas de ações a serem desenvolvidas de maneira autônoma e independente. Entre elas destacam-se:

- a retirada do lixo do córrego;

- o barateamento dos custos de fornecimento de água e energia para os moradores através da "tarifa social";

- a criação de uma área de lazer, incluindo a implantação de um campinho de futebol para as crianças e os adolescentes;

- a divulgação junto a outras comunidades da filosofia da autogestão.

Essas propostas nortearam o início dos trabalhos e serviram de base para desenvolver os projetos e as intervenções na Vila. Como meio de mostrar a força da proposta, buscando uma repercussão tanto dentro da Vila quanto na opinião pública, várias ações de participação comunitária foram desencadeadas, entre elas o mutirão de limpeza do córrego, do qual foram retiradas, em um final de semana, 30 toneladas de lixo. Essas ações obtiveram a repercussão desejada, tanto na comunidade da Vila, quanto na opinião pública, sobretudo pelos efeitos benéficos decorrentes delas, como o fim das enchentes e o quase desaparecimento de animais nocivos à saúde. Após essas ações iniciais foram realizados diversos outros mutirões de limpeza, que do leito do córrego se estenderam aos becos do entorno. Para consolidar essa atuação e para que a população se apropriasse de fato do lugar, foi realizado um concurso entre os jovens da comunidade para a escolha do nome do córrego. O vencedor foi "Córrego da Cidadania", nome muito significativo, que traduz o espírito de solidariedade e cidadania que se tinha instalado na comunidade.

Em âmbito municipal, por suas ações cidadãs, a comunidade recebeu o prêmio "Parceiros" da Superintendência de Limpeza Urbana de Belo Horizonte - SLU e o Prêmio Gentileza Urbana, em reconhecimento à primeira atuação autônoma de limpeza pública na bacia da Pampulha. Foi convidada a participar das comemorações do dia mundial do meio ambiente e da apresentação do Programa de Recuperação e Desenvolvimento Ambiental da Bacia da Pampulha - Propam.

As atuações implementadas pela comunidade tiveram também um êxito para além dos resultados obtidos, que foi aquele de capacitar e convencer os moradores da possibilidade concreta e real de atacar, assim como foi feito com as emergências de ordem ambiental, outras questões também urgentes, como a necessidade de desadensamento do espaço construído, de meIhoria das infraestruturas básicas, de melhoria na educação formal e complementar, e de criação de riquezas.

A prática autogestionária, incorporada, permitiu reconhecer, por parte da comunidade, a necessidade da busca de parcerias com agentes da sociedade organizada e do terceiro setor, e de existência de um vasto campo de possibilidades com parcerias que permitem à comunidade se desvincular do eixo comunidade/poder público, de qualquer instância a que este último pertença, onde se instala uma relação totalizante a partir da força do segundo e que, em muitos casos, chega a se transformar em uma relação de cooptação com a instrumentação da mobilização por parte do poder constituído. 


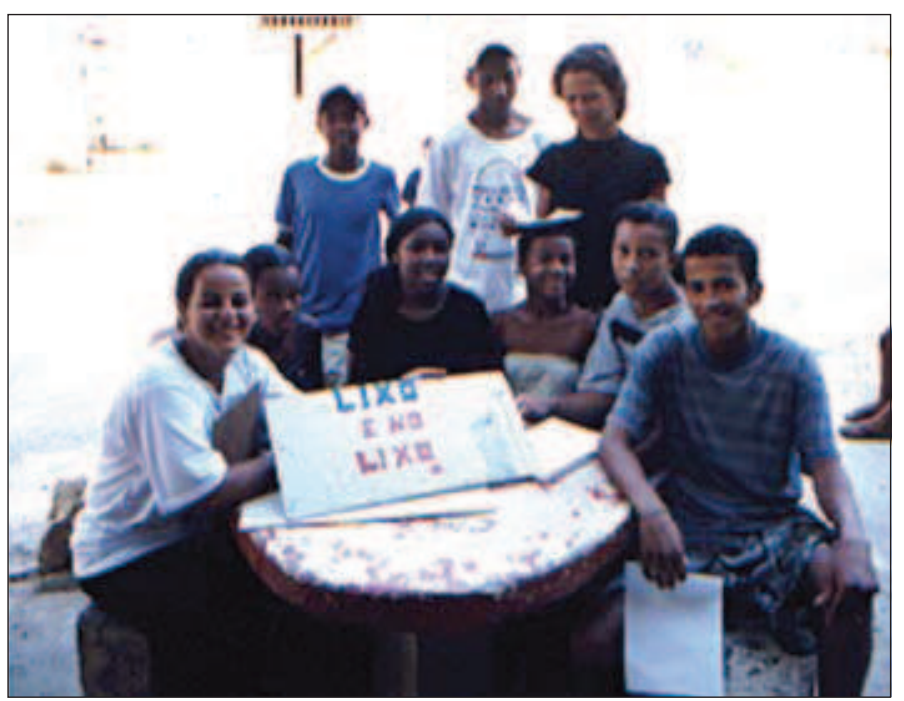

Reconheceu-se, dessa maneira, que a possibilidade de parcerias diferentes, com diferentes atores sociais, podia fazer frente à complexidade dessa realidade. Assim, a comunidade, através de sua liderança, articulou-se e divulgou as ações implementadas, os resultados obtidos e os princípios norteadores desse processo, para buscar parcerias que não tardaram a se concretizar. A comunidade obteve assim, em um tempo relativamente breve, o apoio de importantes organizações filantrópicas como: Habitat para a Humanidade, Lions Clube, Instituto Cidade, Prefeitura de Belo Horizonte, assim como de renomadas instituições de ensino superior com experiência em projetos extensionistas e de inclusão social através da arquitetura e urbanismo, como o Escritório de Integração do Departamento de Arquitetura e Urbanismo da Pontifícia Universidade Católica de Minas Gerais - El/DAU/PUC Minas e empresas cidadãs, cujos objetivos específicos convergiam na busca de soluções abrangentes e permanentes.

Essas práticas e atitudes, entretanto, não se limitaram às parcerias, mas continuaram paralelamente, prova da importância das questões e de como estas foram incorporadas à cultura local da comunidade. A esse respeito a comunidade da Vila Novo Ouro Preto vem participando ativamente, junto ao IC, desde 1997, do Movimento de Cidadania pelas Águas, com a formação de um núcleo local composto de jovens da própria Vila e, em 1998, conseguiu, através do OP, recursos para a elaboração do instrumento de planejamento e ordenamento urbanístico da Vila: o Plano Global Específico - PGE. Esse instrumento, tratado em detalhes mais à frente, contou com a participação ativa da comunidade na coleta, sistematização, diagnóstico e na elaboração das propostas de melhorias previstas. Nessa mesma ocasião, a comunidade conseguiu também recursos do OP para a execução da primeira proposta ou prioridade do PGE, que foi o projeto do Parque Linear ao longo do Córrego da Cidadania.

Em 1999 a comunidade participou como representante da sociedade civil organizada do "Dia Mundial das Águas", implementado pela Secretaria Municipal do Meio Ambiente.
Figura 4 • O grupo "Jovens cidadãos das águas" da Vila Ouro Preto (foto da autora) 


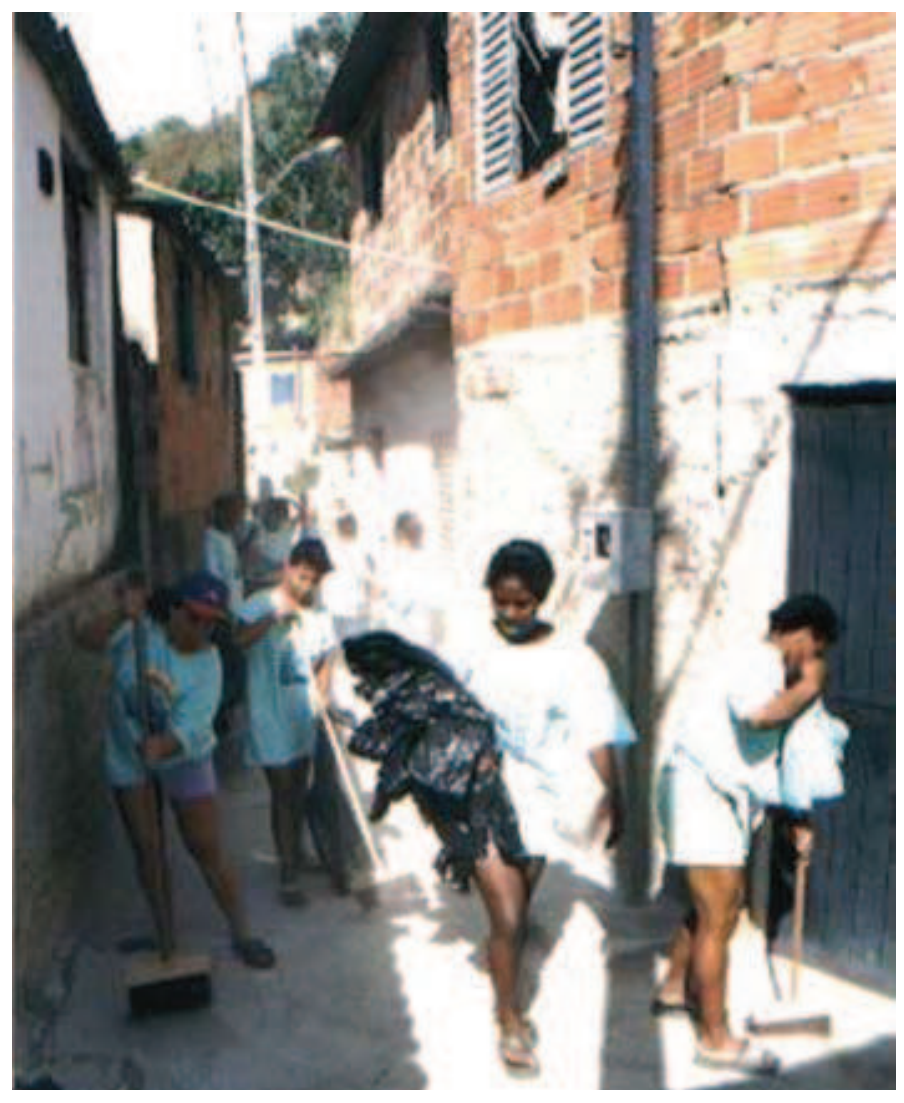

Já no ano de 2000 foi escolhida pelo Hospital Mário Pena para figurar em sua Agenda da Cidadania na categoria meio ambiente; foi também agraciada com o prêmio "Solidariedade" pela Associação dos Funcionários da PBH, e teve aprovado pela Secretaria Municipal do Meio Ambiente seu projeto de expansão da mobilização social para toda a Bacia do Córrego da Cidadania, recebendo financiamento do Fundo Municipal do Meio Ambiente. A atuação dos cidadãos da Vila Ouro Preto tem merecido significativa atenção da imprensa em diversas ocasiões.

Através dos recursos conseguidos no OP e sobretudo graças às parcerias com a sociedade organizada e com os agentes do terceiro setor, a comunidade vem exercendo sua cidadania,

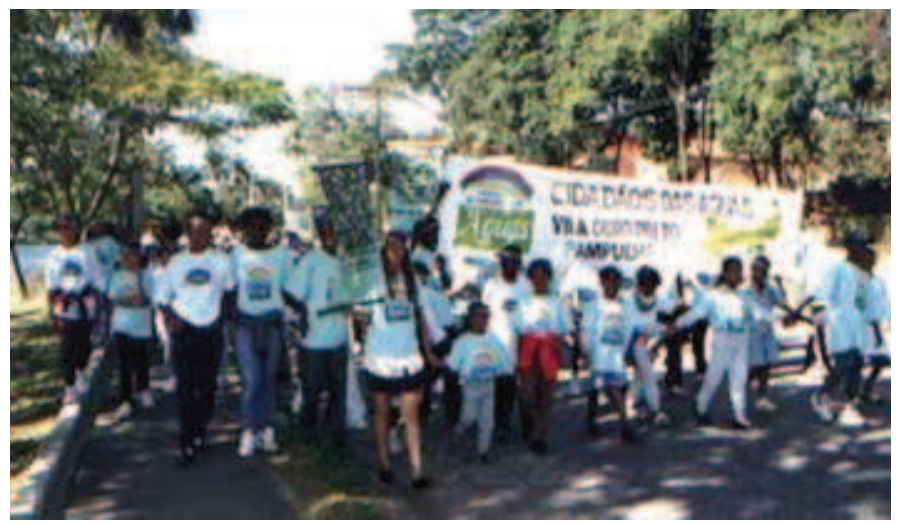

Figura 5 • Um dos mutirões de limpeza das ruas e becos da Vila (foto da autora).

Figura 6 • A mobilização para a limpeza da Vila no dia do meio ambiente (foto da autora).

Cadernos de Arquitetura e Urbanismo, v.16, n.18+19, 2009 


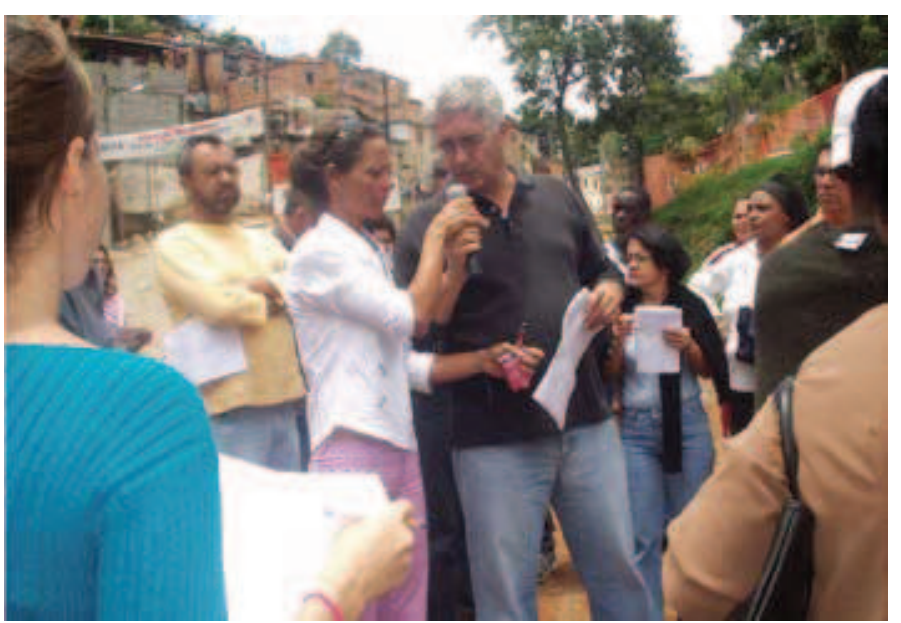

orientando e fiscalizando as melhorias para a Bacia do Córrego da Cidadania, previstas pelo PGE, beneficiando toda a Vila e seu entorno.
Figura 7 • A manifestação em defesa da Lagoa da Pampulha no dia do meio ambiente (foto da autora).

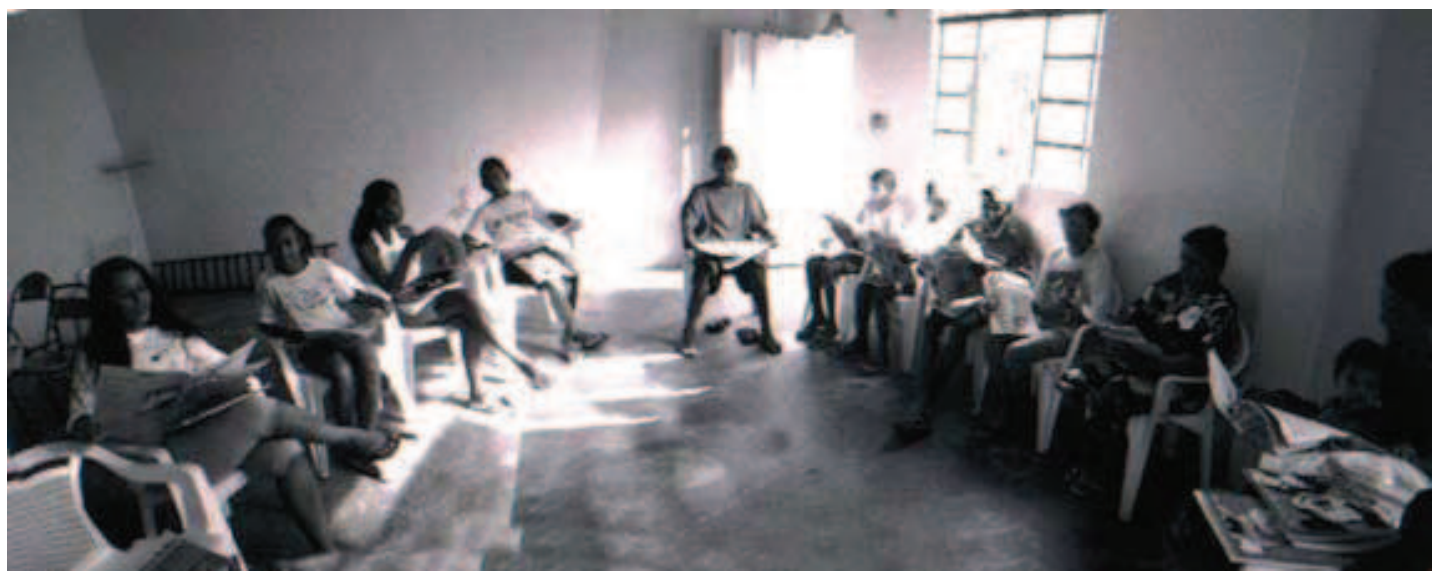

\section{O Plano Global Específico da Vila Novo Ouro Preto}

O PGE é o instrumento urbanístico utilizado, em Belo Horizonte, para o planejamento urbano de vilas e favelas. Esse instrumento, existente desde o começo dos anos 1990, pode ser entendido como um plano de área, pois é destinado unicamente aos assentamentos informais e pretende integrar ações de melhorias ambientais, sociais e de regularização fundiária.

Desde o começo da década de 1980 os assentamentos informais são reconhecidos como áreas formalmente pertencentes à cidade e, como tais, objeto de intervenção legal por parte do poder público para a implementação de melhorias urbanas e habitacionais.

Esse instrumento urbanístico em termos de estratégias de planejamento localiza-se em um meio-termo entre o planejamento compreensivo e o planejamento estratégico, pois constitui um conjunto de propostas de intervenção pautadas nas exigências dos moradores e nos diagnósticos físico-ambiental, socioeco-
Figura 8 • A organização do "Curso de Agentes Ambientais" para adolescentes da Vila (foto da autora).

Caddernos de Arquitetura e Utranismo, v.16, n.18+19, 2009 


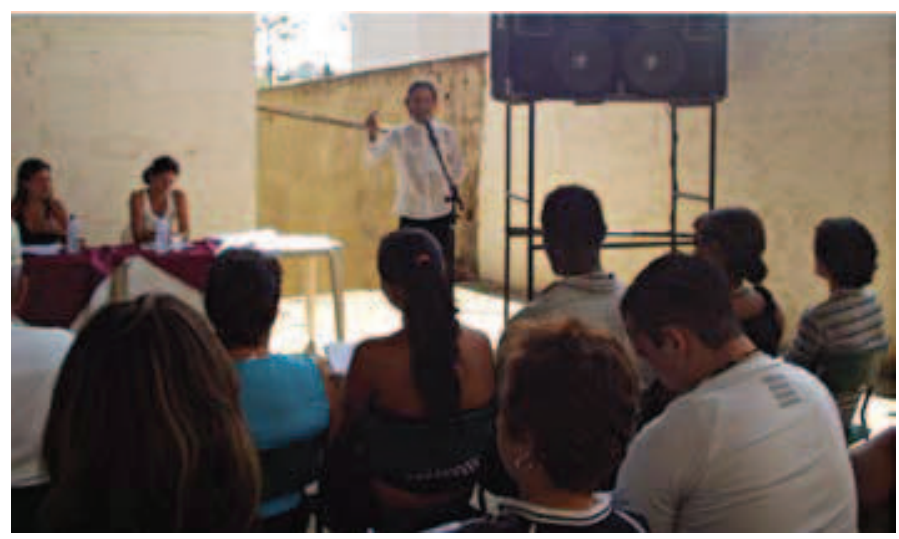

nômico organizativo e jurídico-legal. Essa natureza associada à falta e, talvez, à própria impossibilidade de mecanismos de atualização, sem ter de passar por uma nova elaboração do plano, o torna um instrumento pouco flexível e com a tendência a se tornar rapidamente obsoleto, especialmente se as ações previstas nele não forem colocadas em prática no prazo previsto. Ademais, diante de uma fonte limitada e descontínua de recursos, esta última possibilidade se torna muito concreta. Esses limites afetam esse instrumento urbanístico desde sua formatação e continuam presentes até hoje.

Na Vila Novo Ouro Preto o PGE foi desenvolvido em 2000 pelos técnicos do IC com a participação dos representantes da Vila, proporcionando a estes capacitação e ganho em conhecimento técnico. A comunidade participou ativamente da elaboração do PGE, sendo incluída como mão-de-obra remunerada ao longo do período de elaboração, para o desenvolvimento das pesquisas e dos levantamentos. Esse tipo de participação, embora prevista na metodologia para a elaboração do PGE, revelou-se algo pouco comum na elaboração dos PGEs. Em geral os escritórios, principalmente em razão de cronogramas apertados, preferem criar um pequeno grupo de moradores como grupo consultivo. Em muitos casos o grupo limita-se à liderança local, deixando a coleta e sistematização de dados a cargo de estagiários, em geral estudantes universitários das faculdades de arquitetura e urbanismo, geografia e engenharia.

No caso da Vila Novo Ouro Preto, a elaboração do plano foi uma importante conquista, uma vez que nele estão contidas informações detalhadas sobre o sítio, os moradores e suas moradias, além de propostas de ações de melhorias habitacionais como a relocação das famílias que ocupam as áreas de risco e o projeto de um parque linear ao longo do Córrego da Cidadania.

O PGE, entretanto, não garante para a comunidade a continuidade dos investimentos, pois os parcos recursos provenientes do OP são disputados acirradamente por toda a população de Belo Horizonte. Mas, se de um lado esse instrumento possui sérias limitações, do outro tem uma potencialidade ainda não plenamente conhecida. A esse respeito a própria Vila Novo Ouro Preto está traçando um caminho, pois o PGE coloca-se como um instrumento poderoso nas mãos de uma comunidade consciente das próprias possibilidades e dos próprios recursos para viabilizar a busca e captação de recursos, em âmbitos externos ao setor público, ob-
Figura 9 - Palestra do Projeto Manuelzão (bacia do Rio das Velhas) para adolescentes da Vila (foto da autora). 
jetivando assim a melhoria da qualidade de vida no nível daquela encontrada em locais fora das favelas, garantindo aos moradores da Vila habitação digna, acesso à educação e lazer, culminando na conquista da cidadania plena. Nesse caso, a efetiva incorporação das melhorias pela comunidade tornaria estas últimas mais consistentes e, em algum grau, mais definitivas.

Para a Vila Novo Ouro Preto o PGE define, como diretrizes básicas de intervenção:

- desobstrução de talvegues e nascentes;

- contenção de riscos geológicos e geotécnicos;

- recuperação ambiental e preservação das áreas de recarga das nascentes;

- instalação de rede de esgoto e expansão do fornecimento de água;

- melhoria das articulações viárias internas e externas, incluindose uma via veicular no sentido norte-sul, melhorando o acesso aos equipamentos e serviços e reforçando a legibilidade já existente;

- conferência de exequibilidade jurídica às propostas de intervenção;

- ampliação do polígono da Zeis - Zona Especial de Interesse Social $^{5}$ em aproximadamente $10 \%$ para incluir invasões ocorridas após a sua instituição e até esta data;

- busca da forma jurídica de se regularizar a ocupação nas áreas de alta declividade onde já se realizaram benfeitorias suficientes para a garantia de segurança, uma vez que há parecer técnico favorável da área física para vários pontos;

- atendimento aos fins da Lei do Profavela, envidando esforços no sentido da busca de instrumentos jurídicos que possam conferir a titulação aos possuidores; ${ }^{\circ}$

- remoção e relocação de moradias em áreas de preservação, de risco iminente ou alto e para realização de obras;

- melhoria do conforto ambiental das edificações;

- melhoria dos serviços (em especial a educação, a segurança pública, o transporte, a saúde e a oferta de bens e serviços);

- mobilização e capacitação organizativa para a geração de trabaIho e riqueza;

- criação do centro comunitário para abrigar as atividades organizativas, geradoras de trabalho e riqueza e educativas;

- construção do campo de futebol e escolinha de esportes nas proximidades da Vila;

- estabelecimento de relações estreitas com igrejas do entorno, potencializando a participação dos fiéis nas ações comunitárias;

- interação com a comunidade na busca das soluções jurídicas adequadas, notadamente nos casos de relocação de moradias.

Entende-se, portanto, como o PGE pode ser, de fato, o cartão de visita da comunidade, tornando-se tanto mais poderoso quanto mais são explicitados nele a cultura, os valores e as ideias presentes na comunidade que na mobilização busca, através dele, os recursos para sua implementação.

Poucas são ainda as comunidades que compreenderam esse potencial, e pouco é feito pelo poder público para que as co-
5. A área urbana da cidade de Belo Horizonte é dividida em zonas segundo diretrizes estabelecidas pelo Plano Diretor. A Zeis - Zona Especial de Interesse Social define as regiões da cidade "nas quais há interesse público em ordenar a ocupação, por meio de urbanização e regularização fundiária, ou implementar programas habitacionais de interesse social, e que se sujeitam aos critérios especiais de parcelamento, ocupação e uso do solo..." (Plano Diretor da Cidade de Belo Horizonte).

6. Basta lembrar que alguns moradores da Vila possuem título de posse do terreno comprados na época de parcelamento da área. 
munidades alcancem essa maturidade e essa consciência, mas talvez não seja esse o papel do poder público, ou talvez o poder público deveria se limitar a dar algum tipo de impulso inicial para que a comunidade possa continuar e deslanchar esse processo de maneira autônoma.

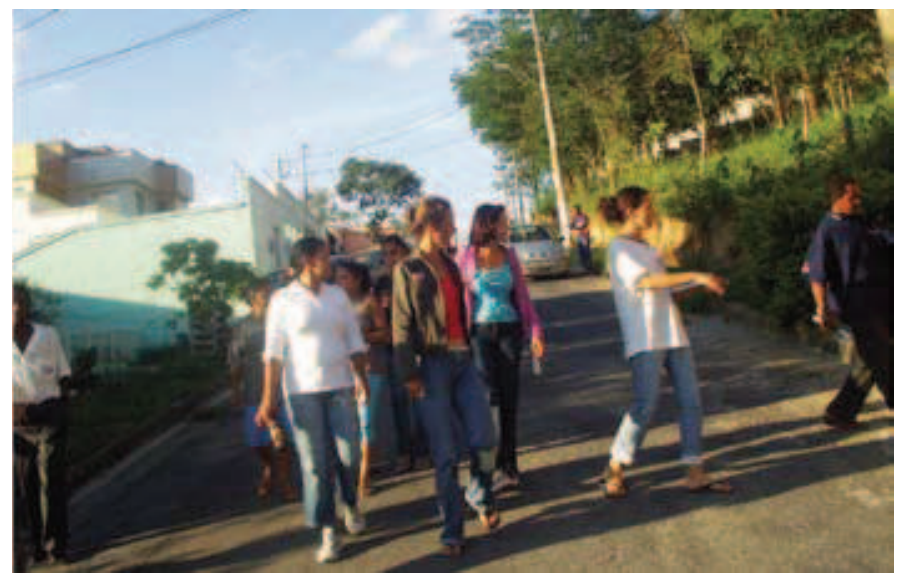

A comunidade da Vila Novo Ouro Preto resulta fazer parte desse pequeno universo, colocando as questões ambientais em primeiro lugar, como valor genuíno, enraizado na cultura local, visto como recurso a ser explorado no sentido da sua tutela, da sua recuperação e melhoria, buscando as formas e os processos necessários a implementar esses objetivos em harmonia com o processo de ocupação.

\section{A primeira etapa do Parque da Cidadania: o Parque Linear}

O PGE propõe um conjunto de intervenções ambientais que tem como objetivo a criação do Parque da Cidadania. A primeira intervenção prevista é a implantação de um parque linear no fundo de vale e ao longo de toda a microbacia do Córrego da Cidadania, visando a recuperação sustentável do meio ambiente, em busca da promoção da qualidade de vida dos moradores da Vila e da região. O projeto propõe a despoluição das águas do Córrego da Cidadania através da implantação de interceptores de esgoto, recuperação e tratamento das nascentes, criação de uma mata ciliar com o intuito de preservar as surgências de água; a ampliação de áreas verdes ao longo do córrego e das faixas de domínio, a criação de áreas de lazer para os moradores e uma via de acesso para caminhão de limpeza urbana e ambulância.

Além de proporcionar a melhoria da qualidade de vida dos moradores da Vila Novo Ouro Preto, tanto essa primeira intervenção quanto a criação do Parque da Cidadania se inserem no contexto mais amplo de intervenções para a despoluição da Lagoa da Pampulha, diminuindo a quantidade de esgoto aí despejado.

As outras intervenções previstas nessa proposta são a criação de um bolsão de área verde a ser implantado nos fundos de vale da sub-bacia às margens do Córrego da Cidadania e suas nascentes, constituindo uma extensão natural do parque linear
Figura $10 \bullet$ Visita da Caravana do Orçamento Participativo à Vila (foto da autora). 
construído no perímetro da Vila, seguindo o sentido do córrego até sua desembocadura no Córrego Flor D’água (Av. Tancredo Neves). A implantação dessa intervenção será viabilizada com recursos conquistados junto ao Fundo Municipal do Meio Ambiente e a outros parceiros financiadores.

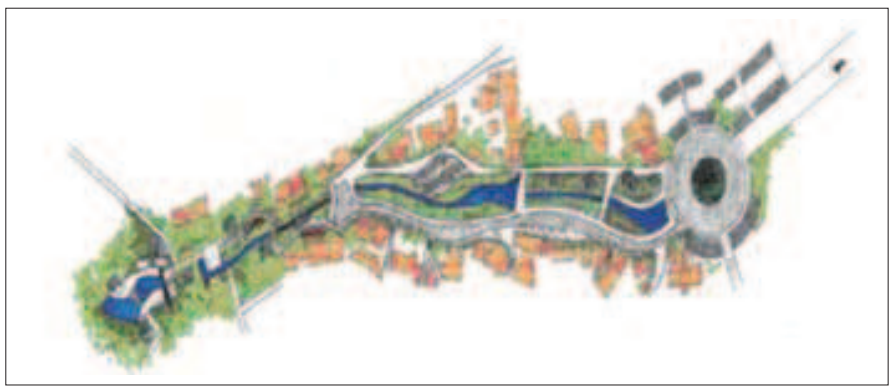

\section{Relocação das famílias}

A implantação do parque linear, ao longo do Córrego da Cidadania, implica a relocação das habitações localizadas na faixa de domínio do córrego ou sobre ele, assim como daquelas próximas às nascentes ou que se encontram em situação de risco alto ou iminente.

Para a elaboração desse projeto, foi assinado um convênio em 2002 entre a Amacidadania e o Habitat para a Humanidade Internacional, 7 mas que, por divergências de caráter metodológico e de desenvolvimento da proposta projetual, não se viabilizou. Como alternativa a Amacidadania procurou o Escritório de Integração do Departamento de Arquitetura e Urbanismo da Pontifícia Universidade Católica de Minas Gerais - El/DAU/PUC Minas para assumir essa empreitada, uma vez que o El já desenvolve projetos nas áreas de reabilitação físico-ambiental de áreas degradadas, com recuperação da capacidade instalada das cidades e desenvolvimento tecnológico da construção civil.

No levantamento do PGE para a implantação do parque linear, foram assinaladas, em um primeiro momento, 35 famílias a serem reassentadas. O El elaborou o levantamento de diversas áreas que poderiam ser utilizadas para tal finalidade, atendendo à exigência dos moradores de que esses terrenos fossem localizados próximo à Vila, uma vez que existem vínculos dos moradores com o local e também laços de família e relações de emprego e renda. Para a escolha das áreas, levaram-se em consideração, além da localização, as condições de infraestrutura, acessibilidade e topografia, além dos custos de aquisição dos terrenos. Após a seleção dos sítios aptos encontrados próximos à Vila, o El elaborou estudos de viabilidade de implantação e definição das tipologias habitacionais de acordo com as exigências dos beneficiados.

\section{Os parceiros}

Em um país onde as ações de intervenção dos governos federal, estadual e municipal para a melhoria da qualidade de vida dos moradores de comunidades carentes costumam demorar, de tal modo que as demandas e necessidades da população acabam
Figura 11 - Estudo para o projeto do Parque da Cidadania.

7. Organização sem fins lucrativos que trabalha com o desenvolvimento de pessoas e comunidades carentes, ajudando na construção e renovação de moradias, além de atuar na administração dos projetos de construção. 
sendo atendidas de maneira autônoma, a filosofia da autogestão e do autogoverno apresenta-se como uma alternativa concreta para encontrar soluções adequadas aos problemas existentes. Embora essa filosofia seja pautada na autonomia da comunidade, delegando ao poder público o papel de ator coadjuvante ou, quando isso se viabiliza, o papel de agente fiscalizador e controlador do uso dos recursos financeiros destinados, faz-se necessário que as comunidades carentes busquem parcerias com entidades da sociedade civil organizada, do terceiro setor, atualmente também com aquelas empresas que têm compromissos sociais e aqueles órgãos ligados à administração indireta.
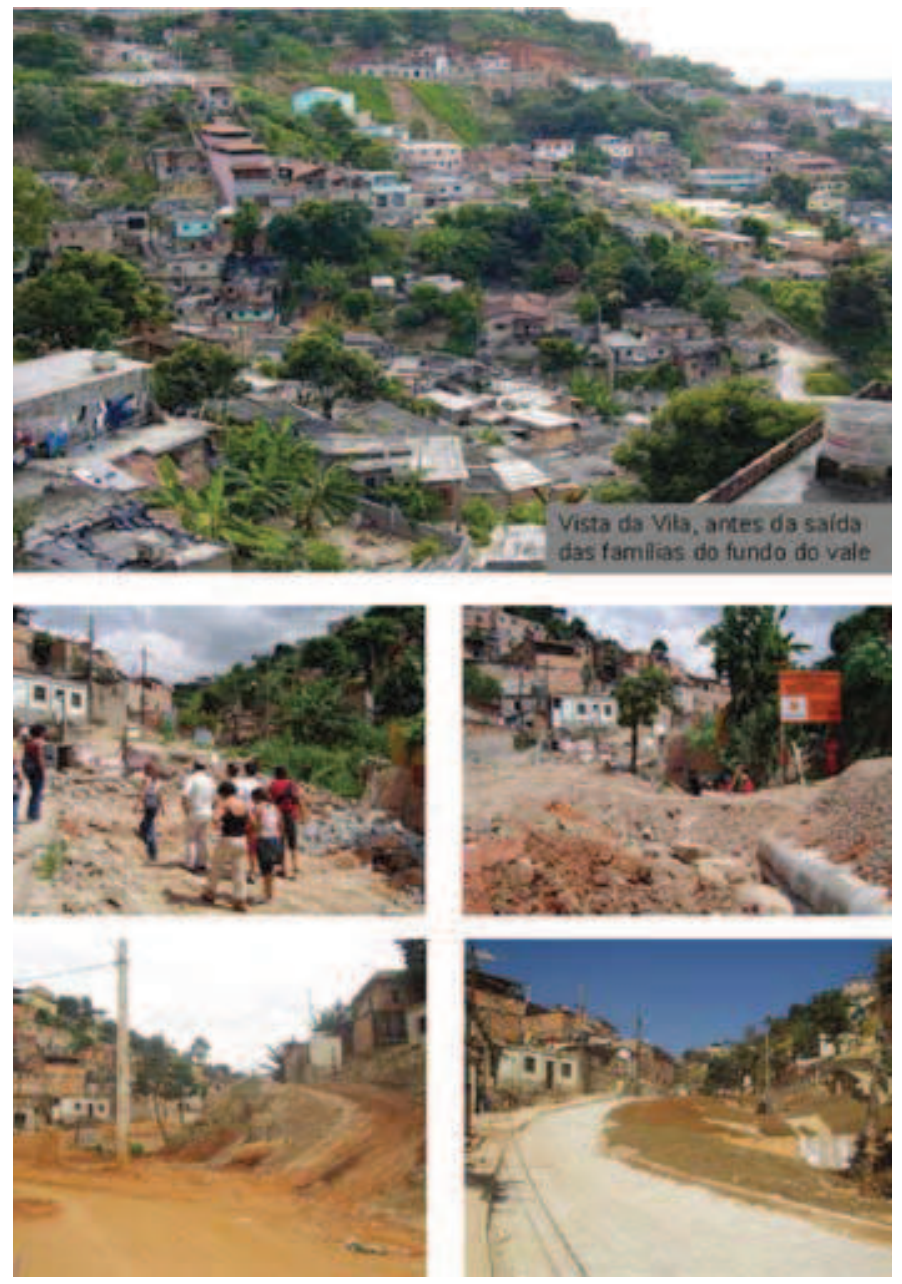

Como foi antecipado, a Vila Novo Ouro Preto, para viabilizar meIhorias de seu ambiente, buscou sistematicamente parcerias com esses agentes, conseguindo construir um grupo de importantes parceiros, alguns dos quais presentes desde o começo da mobilização da comunidade, ajudando o fortalecimento desse processo e outros que entraram em um segundo momento. São eles:

- Instituto Cidade, que como organização sem fins lucrativos tem por objetivo a ação técnica e política em favor da qualidade da vida urbana, do desenvolvimento cultural, social e econômico
Figura 12 • A Vila e os vários estágios da implementação das obras do Parque Linear ao longo do Córrego Cidadania (fotos da autora). 
das cidades e da ampliação dos direitos da cidadania. O Instituto atua em projetos de requalificação ambiental e mobilização social para processos de autogestão, reforçando as ações em favor da despoluição da Lagoa da Pampulha, através da limpeza das águas e cuidado com as nascentes dos córregos que compõem a bacia da Pampulha. Coube ao IC, além da iniciativa de capacitação da comunidade para o projeto de ação com base na autogestão e no autogoverno, a elaboração do PGE com a participação da comunidade e o fornecimento de assessorias técnicas aos moradores da Vila;

- Lions Clube Belo Horizonte Pampulha, uma organização sem fins lucrativos que trabalha em parceria com outras entidades e comunidades. O Lions Clube se responsabiliza pela concretização das parcerias para viabilizar os recursos humanos e materiais necessários à posterior construção das unidades habitacionais, além do apoio à Amacidadania na emissão da documentação necessária à aquisição de materiais de construção autorizados pelos parceiros;

- Escritório de Integração, que é um programa de extensão do Departamento de Arquitetura e Urbanismo da PUC Minas encarregado de desenvolver e aprovar o projeto urbanístico, arquitetônico e os projetos complementares que deverão ser previamente submetidos à aprovação da Urbel, conforme parâmetros definidos na Política Municipal de Habitação. ${ }^{8}$ O El deverá elaborar, também, o planejamento e orçamento da obra e assessorar os serviços de implantação do empreendimento, além da capacitação dos futuros usuários para sua produção e gestão;

- a Companhia Urbanizadora de Belo Horizonte - Urbel, órgão encarregado de executar as políticas habitacionais da Prefeitura Municipal de Belo Horizonte - PBH, subordinado ao Conselho Municipal da Habitação, que, por sua vez, gere o Fundo Municipal da Habitação. A Urbel é responsável pela urbanização de vilas e favelas da cidade, visando à inserção não só desses núcleos no tecido urbano, mas também de suas populações na cidade formal. A Vila Novo Ouro Preto tornou-se objeto dos trabalhos da Urbel a partir de 1999, já que havia conquistado recursos no Orçamento Participativo 1998 para a elaboração do PGE e para a execução das primeiras obras. Compete à Urbel a desapropriação dos terrenos indicados pelo El e aprovados pela comunidade da Vila, para a relocação das 35 famílias com recursos obtidos junto ao OP.
8. De acordo com a Lei de Uso e Ocupação do Solo do Município de Belo Horizonte.
Figura 13 • Visitas das turmas de planejamento habitacional do curso de graduação em Arquitetura e Urbanismo da PUC Minas (fotos da autora).

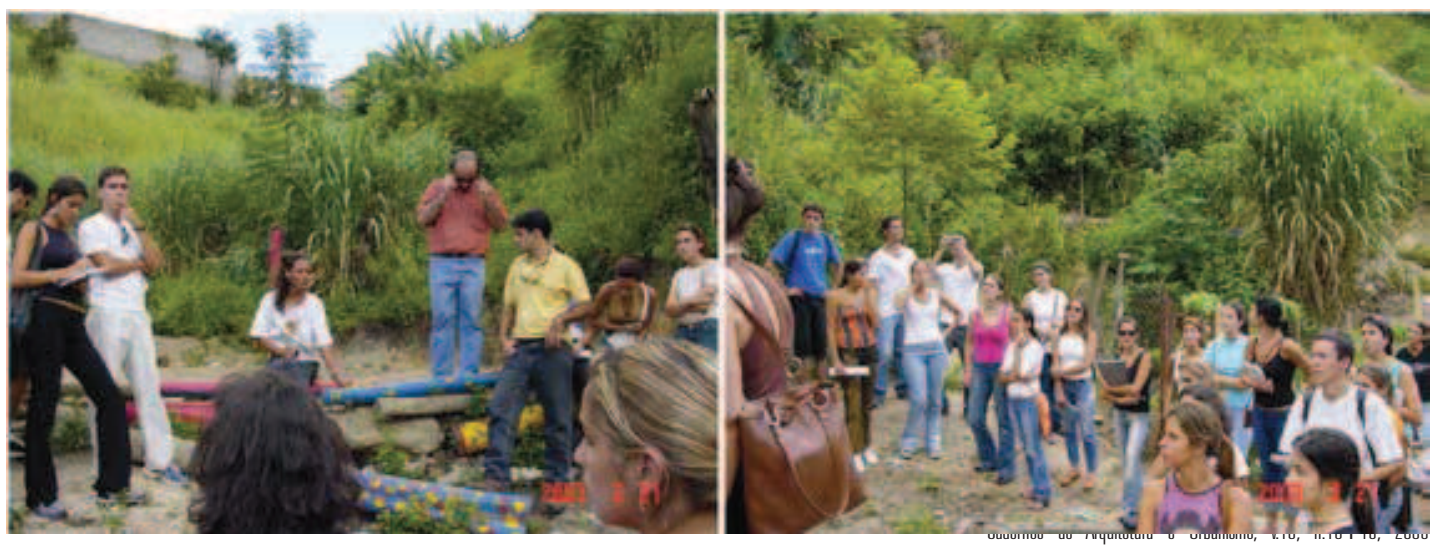




\section{O projeto do "Residencial Cidadania" e a relocação planejada}

A bacia do Córrego da Cidadania é hoje um espaço urbano transformado. As famílias que viviam sobre sua calha foram relocadas temporariamente e constituem um projeto ambicioso que vem coroar as ações cidadãs dessa comunidade.

Após a implementação do Parque Linear ao longo da primeira década do século XXI, o passo sucessivo consiste em reassentar as famílias removidas do fundo de vale para os terrenos adquiridos próximos à Vila, possibilitando assim uma continuidade do convívio cotidiano e das relações de trabalho existentes, formando assim cidadãos capazes de promover a qualidade de vida na comunidade. O projeto adota a autogestão, proporcionando ainda a capacitação das famílias, geração de trabalho e riqueza, habitações dignas, educação, saúde e lazer, culminando na conquista da cidadania plena.

Diante dos resultados já obtidos, das diretrizes apontadas pelo PGE e das perspectivas de trabalho existentes na Vila, pode-se verificar que a parceria da comunidade local com o poder público e com as organizações do terceiro setor, para gestão ambiental da bacia do Córrego da Cidadania, ampara as iniciativas da comunidade e, pela sua unicidade, vem sendo objeto de estudos e pesquisas por parte da academia.

A viabilização da autogestão numa comunidade pouco favorecida economicamente depende, como visto, da capacidade de estabelecer parcerias com entidades privadas e do terceiro setor, pretendendo, afinal:

- no âmbito habitacional buscar condições dignas e acessíveis a todos os moradores da Vila e, conforme indicado pelo PGE, são necessárias a requalificação das habitações em condições precárias, assim como a relocação de parte das famílias devido aos riscos e à degradação ambiental existentes. A relocação prevista será, graças aos terrenos adquiridos, nas proximidades da Vila, já que a maior potencialidade da comunidade está exatamente na união e interdependência de seus moradores, que constituem o que podemos chamar de "família extensiva". Na proposta projetual, tanto na requalificação das habilitações existentes, quanto na relocação e, portanto, nas novas moradias, será observado o conceito pleno de habitação, que contempla, também, o acesso aos serviços públicos e coletivos, incluindo-se aí desde as infraestruturas básicas, até transporte e lazer, garantindo o acesso à cidade formal. De acordo com os princípios da autogestão, muitas alternativas podem ser criadas para atingir a habitação plena, como por exemplo o gerenciamento e a provisão de serviços pela própria comunidade, através de cooperativas de trabalho.

- no âmbito ambiental buscar a recuperação da bacia do Córrego da Cidadania. Com a finalização da implantação do Parque Linear da Vila Novo Ouro Preto, que inclui a captação dos esgotos, a limpeza do córrego e o tratamento da faixa de domínio, reabilitando as margens do córrego e criando áreas de lazer principalmente para crianças e jovens, começam o manejo e apropriação da área. Dará continuidade à intervenção ambiental na Vila a ampliação da cobertura vegetal junto às nascentes, ga- 
rantindo a perenidade de suas águas e aumentando o volume de água limpa entregue à Lagoa da Pampulha. O Parque da Cidadania, de caráter ecológico-habitacional, tomará as margens do córrego em toda a sua extensão, desde a Vila até desaguar no Córrego Flor D'Água, na Avenida Tancredo Neves. As habitações e os equipamentos comunitários, dispostos em total consonância com o meio ambiente, serão construídos segundo os mais modernos métodos de aproveitamento e reaproveitamento de recursos naturais e energéticos.

- na geração de trabalho e renda, estabelecendo cooperativas e grupos de trabalho competentes e respeitados no âmbito regional, que possam gerar renda para os moradores associados e para a comunidade em geral. Os grupos de trabaIho já existentes deverão ser capacitados através de cursos e consultorias para gerir e comerciar sua produção coletiva. Os operários da construção civil, com alto índice de profissionalização na Vila, associar-se-ão em cooperativa para obter trabalho junto ao poder público e à iniciativa privada; as especializações de serviços e produção caseira, como de alimentos, roupas, artesanato, estética e educação complementar, deverão também ser organizadas e fomentadas de modo a atender às necessidades dos habitantes da própria Vila e dos arredores, gerando uma maior circulação interna de renda. Através de cursos profissionalizantes, será capacitada parte da população local para ingressar no mercado formal de trabaIho de Belo Horizonte.

\section{A situação atual}

O Parque da Cidadania só foi possível porque as famílias que moravam sobre o córrego se mobilizaram pela melhora de suas condições de moradia e saúde. A opção pela relocação foi decisão de algumas famílias que não queriam perder os vínculos existentes nessa comunidade e queriam continuar lutando por uma Vila melhor.

A Vila Novo Ouro Preto é considerada, atualmente, como a única vila que possui mais de $80 \%$ das obras previstas pelo PGE já executadas.

As várias etapas de projeto que vêm ocorrendo desde 2002 são acompanhadas de perto pelo El, que fornece assessoria técnica como atividade de extensão universitária por alunos da graduação de Arquitetura e Urbanismo PUC Minas, que acompanham a cada semestre a evolução das obras e o processo de execução, dentro das disciplinas de Política Habitacional e Planejamento Habitacional.

A participação dos alunos tanto nas atividades de extensão quanto nas atividades acadêmicas, dentro das disciplinas mencionadas acima, permitiu aproximar a academia da realidade cotidiana, no primeiro caso tendo de atender a demandas urgentes com racionalidade e objetividade, no segundo dando espaço à pesquisa e à criatividade para encontrar soluções que busquem associar as novidades tecnológicas com práticas de implementação e gestão sustentáveis, segundo as palavras da própria líder local: 


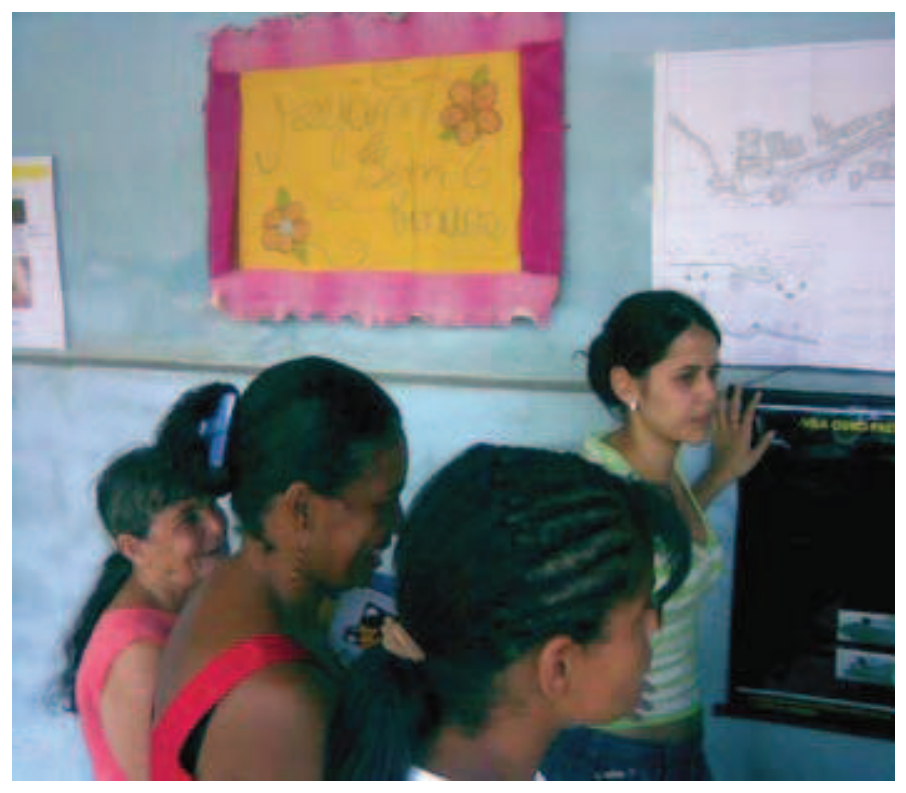

Com trabalhos de campo e estudos e propostas de viabilização de relocação, permitiu que o conhecimento acadêmico passasse através da prática e o meio fosse transformado pela teoria apreendida de forma efetiva em soluções e desenvolvimento de tecnologias para a construção, em projetos que interferiram de forma positiva na visão de ocupação de áreas de nascentes e encostas.

A comunidade assim participa das atividades e das propostas acadêmicas que pretendem ser uma contribuição no sentido de fortalecer a comunidade dentro de um processo de troca mútua no qual a universidade coloca à disposição da comunidade o saber técnico. A comunidade, através de seus representantes, foi levada à universidade participando nos exames finais através das atividades de avaliação e a Vila já foi objeto de trabalhos de graduação, o último dos quais se propôs desenvolver uma metodologia de projeto participativo para o processo de relocação planejada e foi apresentado no segundo semestre de 2006, participando do concurso nacional de trabalhos finais de Arquitetura e Urbanismo - Ópera Prima. Esse trabalho de graduação foi adotado pelas famílias como início da etapa de projeto de relocação.

Neste ano, a Vila Novo Ouro Preto foi material de estudo e trabalho desenvolvido por alunos desta universidade com o tema agraciado pelo Concurso Nacional de Ideias - reforma urbana, recebendo menção honrosa pelas propostas desenvolvidas para melhorias de habitações de interesse social no Brasil.

A situação da Vila Novo Ouro Preto, apesar das muitas similaridades com tantas outras comunidades carentes, apresenta 0 diferencial da autoestima através do trabalho, da educação e da atuação democrática que estimula os parceiros por possuir a potencialidade de ser replicada em outras muitas comunidades, para que estas também possam conquistar novos parâmetros de cidadania e qualidade de vida.
Figura $14 \cdot$ As propostas de reassentamento e melhorias

habitacionais da Vila apresentadas pelos estudantes das turmas de planejamento habitacional do curso de graduação em Arquitetura e Urbanismo da PUC Minas (foto da autora). 


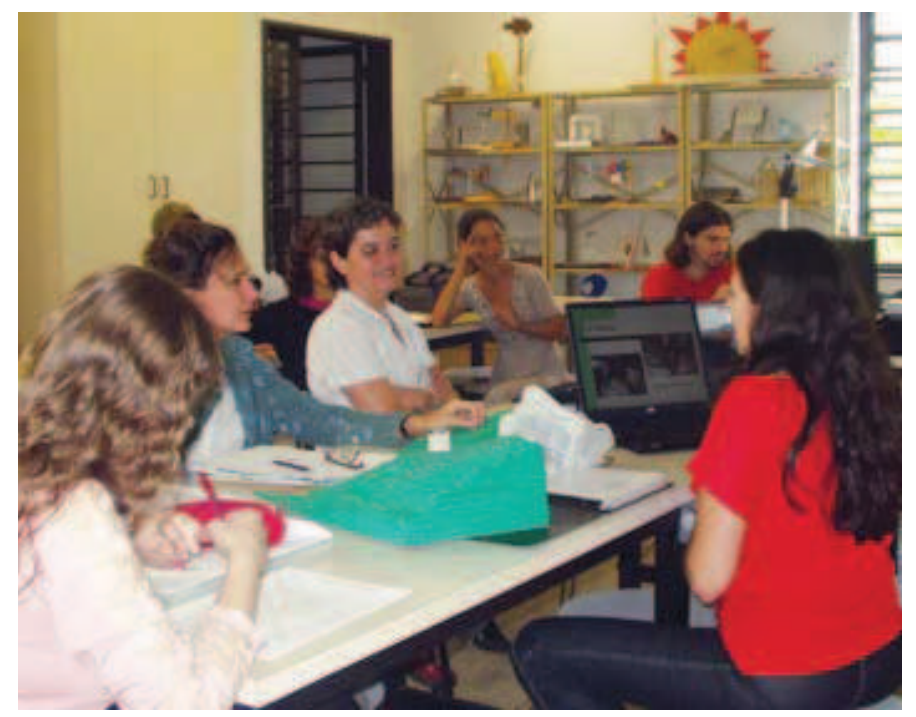

Conclusão

A conscientização e suas próprias capacidades distinguem a Vila Novo Ouro Preto das outras vilas e favelas de Belo Horizonte.

Não se pretende sustentar a tese de que o poder público não tenha que se encarregar dessas questões, pelo contrário, o que se pretende demonstrar é que a potencialização das possibilidades de melhoria dos assentamentos informais passa pela mobilização da comunidade em outros âmbitos, cada vez mais disponíveis, alcançáveis e abertos a parcerias.

O exemplo da Vila Novo Ouro Preto aponta em direção a uma evolução positiva do espírito daquela parte da sociedade brasileira notoriamente excluída do acesso à cidade, herdeira de uma postura passiva, na busca da integração com outros setores da sociedade civil para que possa de fato ser encontrado um denominador comum para a melhoria ambiental do meio urbano.

Segundo Vieira,

no processo de mobilização da sociedade da Vila Novo Ouro Preto, que se encontra em andamento, a conscientização da população foi o principal fator para uma transformação e mudança de atitude. A Vila Novo Ouro Preto serve como exemplo para outras comunidades, pois extrapola uma metodologia que pode ser aplicada em outros contextos de informalidade, sustentando a tese de que a emancipação da comunidade no seu sentido mais amplo e integral passa através da compreensão do meio ambiente local e das suas dinâmicas e condicionantes para enxergar nelas recursos e valores a serem compartilhados dentro da comunidade e na sociedade como um todo. (VIEIRA, 2002)

Não se pretende tampouco desconhecer as dívidas que o resto da sociedade tem para com essas populações, mas evidenciar que uma nova consciência está prestes a desabrochar e quem sabe até nortear e chefiar transformações no nosso meio urbano.
Figura 15 - Apresentação do trabalho final de graduação - Metodologia para Projetação - Relocação planejada.inas (foto da autora). 


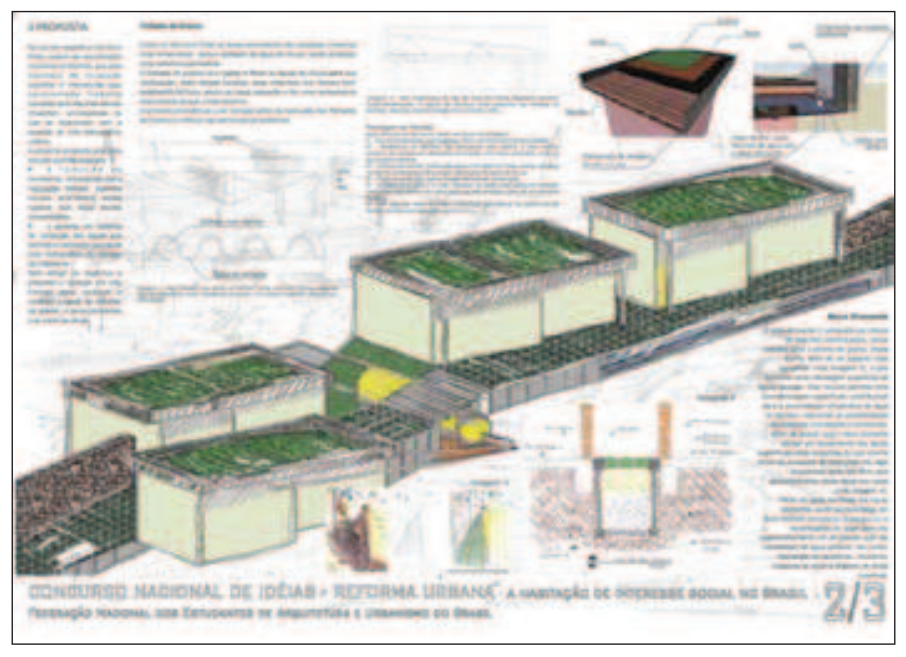

A carta aberta do movimento Amacidadania à $\mathrm{PBH}$, da qual transcreve-se um trecho, verdadeiro manifesto da consciência ambiental cidadã, será tomada cada vez com mais seriedade pela sociedade, pela academia, pelo poder público, em todas as suas instâncias, e pelas outras inúmeras comunidades carentes que compõem o universo urbano das cidades e metrópoles brasileiras.

O projeto que nós ganhamos no Orçamento Participativo (...) é de recuperação do córrego e melhoria da qualidade de vida de toda a população residente no local. É o projeto de um parque com água limpa, áreas de lazer, via de acesso local para caminhão de lixo, ambulância etc. Não é o projeto de uma rua com área verde do lado. A rua é consequência do parque e não o contrário. É um projeto de vida, não um projeto viário. $O$ que nós queremos é um projeto ambiental e habitacional, que melhore a qualidade de vida na vila e na cidade (...). Queremos qualidade, não quantidade. Queremos uma intervenção que transforme realmente a imagem do lugar. Não queremos uma obra de favela. Acreditamos que ruas em favelas não atraem investimento, mas um projeto ambiental, habitacional e social sim. A importância desta obra vai muito além da intervenção em si. Ela é, sim, a nossa possibilidade de captação de investimentos para a Vila. Não nos interessa agora se a rua vai chegar até ali ou até aqui. Nos interessa é a qualidade do parque, como vão ser nossos espaços de lazer, como vai ser recuperado nosso córrego, como vai ser feita a coleta do lixo. Não estamos falando de ruas, estamos falando de vidas... ${ }^{9}$

\section{Agradecimentos}

A Édina Barbosa, pela dedicação e profissionalismo para com a equipe do El; ao Paulo Dimas Menezes, pelo empenho e esclarecimentos acerca do tema; e aos moradores da Vila Novo Ouro Preto, pelo carinho e receptividade.
Figura 16 • Uma proposta de reassentamento sustentável apresentada no Concurso Nacional de Ideias da Fenea - Federação Nacional dos Estudantes de Arquitetura e Urbanismo (foto da autora).
9. Trecho de carta aberta do movimento Amacidadania à Prefeitura de Belo Horizonte.

Cadernos de Arquitetura e Urbanismo, v.16, n.18+19, 2009 


\section{Referências}

BELO HORIZONTE (MG) Prefeitura. Legislação urbanística do município de Belo Horizonte: plano diretor : parcelamento, ocupação e uso do solo urbano. Belo Horizonte: Prefeitura, 1996.

CAMPOS FILHO, Candido Malta. Reinvente seu bairro: caminhos para você participar do planejamento de sua cidade. São Paulo: Ed. 34, 2003.

COMPANHIA URBANIZADORA DE BELO HORIZONTE. Plano global específico da Vila novo Ouro Preto. Belo Horizonte: Urbel, 2000.

CONTI; Alfio. Urbanização de vilas e favelas em Belo Horizonte: resgatando a história do Plano Global Específico. Belo Horizonte. No prelo.

COSTA MOURA; Heloisa. A duração das cidades: sustentabilidade e risco nas políticas urbanas. In: ACSELRAD, Henri (Org.). Coleção espaços do desenvolvimento. Rio de Janeiro: DP\&A, Crea-RJ, 2001.

LYNCH, Kevin. A imagem da cidade. São Paulo: Martins Fontes, 1998.

MORETTI, Ricardo S. Normas urbanísticas para habitação de interesse social: recomendações para elaboração. São Paulo: IPT, 1997.

VIEIRA, Roberta. Utopia: pode-se tornar realidade. I CONGRESSO NACIONAL DE MONOGRAFIA: MEIO AMBIENTE SOCIAL E ERRADICAÇÃO DA POBREZA, 2002.

\section{Endereço para correspondência}

Alfio Conti

contialfio@gmail.com

Rua Oliveira 71 - Cruzeiro

30310-150 - Belo Horizonte

Adriana Ribeiro Gouveia

adrianagou.arq@gmail.com

Rua dos Bandolins 215 / 403 - Conjunto Califórnia I

CEP 30.850-470 - Belo Horizonte 